\title{
GABA Release and Uptake Regulate Neuronal Precursor Migration in the Postnatal Subventricular Zone
}

\author{
Anna J. Bolteus and Angélique Bordey \\ Departments of Neurosurgery and Cellular and Molecular Physiology, Yale University, New Haven, Connecticut 06520-8082
}

In the postnatal subventricular zone (SVZ), astrocyte-like cells tightly encapsulate chains of migrating neuronal precursors, although an influence of the astrocyte-like cells on precursor migration has not yet been demonstrated. Cell migration was studied in acute sagittal brain slices to determine whether GABA signaling between astrocyte-like cells and neuronal precursors controls the speed of neuronal precursor migration in the anterior SVZ and rostral migratory stream of juvenile and adult mice. Application of GABA at $10 \mu \mathrm{M}$, a nondesensitizing concentration for $\mathrm{GABA}_{\mathrm{A}}$ receptors $\left(\mathrm{GABA}_{\mathrm{A}} \mathrm{Rs}\right.$ ), reduced the rate (mean of $\sim 50 \mu \mathrm{m} / \mathrm{hr}$ ) of cell migration by $21 \%$ via $\mathrm{GABA}_{\mathrm{A}} \mathrm{R}$ activation. Application of the $\mathrm{GABA}_{\mathrm{A}} \mathrm{R}$ antagonist bicuculline enhanced the migration rate by $30 \%$, suggesting that endogenous $\mathrm{GABA}$ tonically reduces the speed of cell migration via $\mathrm{GABA}_{\mathrm{A}} \mathrm{R}$ activation. Using immunohistochemistry, we found that astrocyte-like cells express the high-affinity GABA transporter subtype GAT4 on processes ensheathing neuronal precursors that contain GABA. Inhibition of GABA uptake into astrocyte-like cells or enhancement of GABA release from neuronal precursors during high $\mathrm{K}^{+}$application further reduced the migration rate by increasing ambient GABA levels. GABA altered the migration speed by interfering with intracellular $\mathrm{Ca}^{2+}$ signaling independently of cell depolarization, because high $\mathrm{K}^{+}$application did not alter the speed of cell migration in the presence of bicuculline. These data indicate that astrocyte-like cells create a microenvironment in which their uniquely positioned $\mathrm{GABA}$ transporters control the degree of $\mathrm{GABA}_{\mathrm{A}} \mathrm{R}$ activation and the migration of neuronal precursors.

Key words: astrocyte (astroglia); calcium (Ca); GABAergic; proliferation; receptor; transport; rostral migratory stream

\section{Introduction}

The postnatal subventricular zone (SVZ), also called the subependymal zone (Boulder Committee, 1970), contains the largest pool of dividing neural precursors in the adult rodent brain. The SVZ consists of a network of interconnected channels comprised mostly of two major cell types (Doetsch et al., 1997; GarciaVerdugo et al., 1998; Temple and Alvarez-Buylla, 1999), class III $\beta$-tubulin (TuJ1)-immunopositive neuronal precursors $(\sim 80 \%)$ closely ensheathed by glial fibrillary acidic protein (GFAP)immunopositive cells $(\sim 20 \%)$. Within the channels, neuronal precursors are densely packed and migrate throughout the SVZ and along the rostral migratory stream (RMS) toward the olfactory bulb where they differentiate into interneurons (Lois et al., 1996; Luskin, 1998; Belluzzi et al., 2003; Carleton et al., 2003). The $\mathrm{GFAP}^{+}$cells of the SVZ are thought to derive from radial glial cells (Tramontin et al., 2003) and display characteristics of stem cells (Doetsch et al., 1997; Garcia-Verdugo et al., 1998). However, whereas radial glial cells provide a physical substrate for guiding precursor migration, the function of SVZ GFAP ${ }^{+}$

\footnotetext{
Received May 24, 2004; revised June 22, 2004; accepted July 12, 2004.

This work was supported by National Institutes of Health Grant R21NS044161-01. We thank Drs. C. Broberger, B. Ehrlich, M. Sarkisian, P. Uhlen, and A. Williamson for valuable comments on this manuscript, Dr. C. Greer for comments and for providing access to an image acquisition system for immunostaining, and Dr. L. Bolteus for help with computational programming for analyzing cell migration. We are very grateful to Dr. Cheryl Garganta, who measured GABA levels in solution using mass spectrometry.

Correspondence should be addressed to Dr. Angélique Bordey, Department of Neurosurgery, Yale University School of Medicine, 333 Cedar Street, New Haven, CT 06520-8082. E-mail: angelique.bordey@yale.edu. DOI:10.1523/JNEUROSCI.1999-04.2004

Copyright $\odot 2004$ Society for Neuroscience $\quad$ 0270-6474/04/247623-09\$15.00/0
}

cells (called astrocyte-like cells from now on in this study) on precursor migration remains unknown.

Astrocytes $\left(\mathrm{GFAP}^{+}\right.$cells elsewhere in the brain) ensheath neuronal processes and remove synaptically released neurotransmitters via high-affinity uptake systems, thereby regulating synaptic activity (Haydon, 2001). Although SVZ cells do not form synapses (Doetsch et al., 1997; Garcia-Verdugo et al., 1998; Temple and Alvarez-Buylla, 1999), the neurotransmitter GABA is abundantly available in SVZ precursors (Wang et al., 2003a), and migrating neuronal precursors express $\mathrm{GABA}_{\mathrm{A}}$ receptors $\left(\mathrm{GABA}_{\mathrm{A}} \mathrm{Rs}\right.$ ) (Stewart et al., 2002; Nguyen et al., 2003; Wang et al., 2003a). Furthermore, GABA alters the proliferation of postnatal neuronal precursors (Nguyen et al., 2003). Ambient GABA may also regulate neuronal precursor migration, as observed for embryonic cells elsewhere in the brain (Barker et al., 1998; Fueshko et al., 1998). However, the role of astrocyte-like cells of the SVZ on the regulation of GABA levels, $\mathrm{GABA}_{\mathrm{A}} \mathrm{R}$ activation, and cell migration has not been examined. Such information is essential for understanding how GABA signaling influences the behavior of precursors in the postnatal SVZ.

In this study, we monitored the migration of neuronal precursors in acute sagittal slices from mice under conditions that affect $\mathrm{GABA}_{A} \mathrm{R}$ function or GABA release and uptake. We found that endogenous GABA tonically reduces the speed of neuronal precursor migration via $\mathrm{GABA}_{\mathrm{A}} \mathrm{R}$ activation. Furthermore, enhancement of GABA release from neuronal precursors or inhibition of GABA uptake into astrocyte-like cells further reduces the speed of neuronal precursor migration. These data demonstrate 
that astrocyte-like cells create a microenvironment in which GABA release and uptake tightly control neuronal precursor migration by influencing the degree of $\mathrm{GABA}_{\mathrm{A}} \mathrm{R}$ activation. Alterations in GABA signaling and astrocyte-like cell properties could thus profoundly affect postnatal neurogenesis.

\section{Materials and Methods}

Preparation of acute slices and acute RMS explants. Preparation of $215 \mu \mathrm{m}$ coronal or sagittal slices containing the SVZ and/or RMS from juvenile [postnatal day 14 (P14) to P20] and adult mice (3-4 months of age) was essentially as previously reported for coronal slices (Wang et al., 2003a,b). Sagittal slices included the olfactory bulb. To obtain acute explants, the RMS was cut out from coronal slices using glass pipettes (internal diameter, $1.1 \mathrm{~mm}$; Sutter Instruments, Novato, CA). After $>1$ hr in oxygenated artificial CSF (ACSF), slices were placed in a flowthrough chamber, held in position by nylon mesh glued to a U-shaped platinum wire, and continuously superfused with oxygenated ACSF (for patch-clamp recordings) or serum-free Eagle's Basal Medium with Earle's salts (BME) (for migration studies). The solution was stably heated to $37^{\circ} \mathrm{C}$ by using a series 20 platform and an SF-28 in-line heater (Warner Instruments, Hamden, CT). Both patch-clamp and migration experiments were performed on an upright Olympus BX50WI microscope (Olympus Optical, Melville, NY) equipped with water-immersion Nomarski phase-contrast and fluorescence optics $(60 \times$; numerical aperture, 0.9). The ACSF contained (in $\mathrm{mm}$ ): $125 \mathrm{NaCl}, 2.5 \mathrm{KCl}, 2 \mathrm{CaCl}_{2}, 1$ $\mathrm{MgCl}_{2}, 1.25 \mathrm{NaH}_{2} \mathrm{PO}_{4}, 25 \mathrm{NaHCO}_{3}$, and 10 glucose, $\mathrm{pH} 7.4$, when equilibrated with $95 \% \mathrm{O}_{2}-5 \% \mathrm{CO}_{2}$. The BME medium was supplemented with $18.6 \mathrm{~mm} \mathrm{NaHCO}_{3}, 1 \% \mathrm{BSA}, 5 \mathrm{mg} / \mathrm{l}$ insulin, $5 \mathrm{mg} / \mathrm{l}$ transferrin, $5 \mu \mathrm{g} / \mathrm{l}$ sodium selenite, $20 \mathrm{U} / \mathrm{ml}$ penicillin-streptomycin, $2 \mathrm{~mm} \mathrm{L-glutamine,} 27$ mu glucose, and $7.9 \mathrm{~mm} \mathrm{NaCl}$ (Kakita and Goldman, 1999).

Time-lapse videomicroscopy to study cell migration in acute sagittal slices. Only sagittal slices that contained the SVZ and entire RMS were selected to study cell migration. Images of $80 \times 100 \mu \mathrm{m}$ fields of view were acquired at $10 \mathrm{sec}$ intervals for $25 \mathrm{~min}$ using LG3 frame grabber (Scion Corporation, Frederick, MD) to generate a time-lapse movie. To examine the effect of drugs on cell migration, six movies were acquired per drug: three under control conditions and three with a drug. Only one drug was tested per slice. The rate of cell migration remained stable over the course of $5 \mathrm{hr}$ control. To evaluate the effect of GABA transporter blockers and $\mathrm{KCl}$ on cell migration, the perfusion was stopped and slices were incubated in a custom-made closed chamber containing $1 \mathrm{ml}$ of oxygenated BME solution. Drugs were applied by bath (unless otherwise noted) and directly diluted in oxygenated ACSF. Drugs used at $>1 \mathrm{~mm}$ replaced equimolar $\mathrm{NaCl}$. When a low- $\mathrm{Ca}^{2+}$ extracellular solution was used, $1 \mathrm{~mm}$ EGTA was added, giving a calculated free $\left[\mathrm{Ca}^{2+}\right]$ of $0.8 \mathrm{~mm}$ (instead of $1.8 \mathrm{~mm}$ ) using the software WinMAXC (version 2.05; C. Patton, Stanford University, Stanford, CA). 1-[2-[tris(4-methoxyphenyl)methoxy] ethyl]-(S)-3-piperidinecarboxylic acid (SNAP5114) and bicuculline were purchased from (Ballwin, MO), and BAPTA-AM and the BME medium were from Molecular Probes (Eugene, OR) and Invitrogen (San Diego, CA), respectively. All of the other drugs and chemicals were obtained from Sigma (St. Louis, MO).

Electrophysiology. Whole-cell patch-clamp recordings were obtained as previously described (Edwards et al., 1989; Wang et al., 2003a,b). Patch pipettes were pulled from thin-walled borosilicate glass (World Precision Instruments, Sarasota, FL) on a PP-83 puller (Narishige, Tokyo, Japan). Pipettes had resistances of 6-8 M $\Omega$ when filled with an intracellular solution containing the following: $110 \mathrm{~mm} \mathrm{KCl}$ or $15 \mathrm{~mm} \mathrm{KCl}$ and $95 \mathrm{~mm}$ K-gluconate when noted, $1.0 \mathrm{~mm} \mathrm{CaCl}_{2}, 10 \mathrm{~mm}$ EGTA, $10 \mathrm{~mm}$ HEPES, $0.1 \%$ lucifer yellow (dilithium salt), and an ATP-regenerating solution that included $4 \mathrm{~mm} \mathrm{~K}{ }_{2} \mathrm{ATP}, 20 \mathrm{~mm} \mathrm{~K}_{2}$-phosphocreatine, $50 \mathrm{U} / \mathrm{ml}$ creatine phosphokinase, and $6 \mathrm{mM} \mathrm{MgCl}_{2}$ (Forscher and Oxford, 1985; MacDonald et al., 1989). The $\mathrm{pH}$ and the osmolarity were adjusted to 7.2 (with Tris-base) and $290 \mathrm{mOsm}$, respectively. The liquid junction potential was not corrected. Whole-cell recordings were performed using an Axopatch 200B amplifier, and current signals were low-pass filtered at $2-5 \mathrm{kHz}$ and digitized on-line at $5-20 \mathrm{kHz}$ using a Digidata 1320 digitizing board (Axon Instruments, Foster City, CA) interfaced with a Dell
(Round Rock, TX) computer. Settings were determined by compensating the transients of a small $(-5 \mathrm{mV}) 10 \mathrm{msec}$ voltage step. Capacitive and leak currents were not subtracted.

Immunohistochemistry. Immunostaining was performed as described recently (Wang et al., 2003a). Acutely prepared slices or slices used for patch-clamp recording were fixed for $3 \mathrm{hr}$ in $4 \%$ paraformaldehyde in PBS containing $4 \%$ sucrose (PBSS). Slices were washed in PBSS, permeabilized for 20 min with $0.1 \%$ Triton X-100 in PBSS, and blocked overnight at $4^{\circ} \mathrm{C}$ in PBSS containing $1 \%$ bovine serum albumin (Sigma), $10 \%$ goat or donkey serum, and $0.1 \%$ Triton X-100. The next day, slices were incubated overnight at $4^{\circ} \mathrm{C}$ with primary antibody against GAT4 or GAT1 (rabbit; 1:100; Chemicon, Temecula, CA), GABA (rabbit; 1:500; Sigma), neuronal TuJ1 (monoclonal; 1:500; Covance Research Products, Grand Rapids, MI), polysialic acid-neural cell adhesion molecule (PSANCAM) (mouse; 1:500; Chemicon), and/or glutamate-aspartate transporter (GLAST) (rabbit; 1:100; Chemicon) in PBSS with 1\% BSA and $0.1 \%$ Triton X-100. The next day, slices were washed and then incubated for $90 \mathrm{~min}$ with the appropriate Alexa Fluor secondary antibody (1:800; Molecular Probes) at room temperature. Finally, after three washes in PBSS, slices were mounted on glass coverslips with 4',6'-diamidino-2phenylindole (DAPI)-containing mounting medium (VectashieldDAPI; Vector Laboratories, Burlingame, CA) and viewed on an epifluorescence microscope (BX51; Olympus Optical). Appropriate control experiments such as the absence of the primary antibodies were performed (data not shown).

Measurements of GABA levels using mass spectrometry. Four acute explants from one hemisphere were used as control while those from the opposite hemisphere were treated with various drugs. For each drug, experiments were performed in triplicate. The explants were placed in 20 $\mu \mathrm{l}$ of $95 \% \mathrm{O}_{2}-5 \% \mathrm{CO}_{2}$-saturated $\mathrm{BME}$ and placed in a $95 \% \mathrm{O}_{2}-5 \%$ $\mathrm{CO}_{2}$-saturated humidified chamber at $37^{\circ} \mathrm{C}$ for $1 \mathrm{hr}$ before collecting and freezing $\left(-20^{\circ} \mathrm{C}\right)$ the supernatant. GABA concentration was measured by liquid chromatography-tandem mass spectrometry after butylation. Briefly, $10 \mu \mathrm{l}$ of sample was mixed with $20 \mu \mathrm{l}$ of $\mathrm{d}_{6}$-GABA $(0.5 \mu \mathrm{M}$; Cambridge Isotope Laboratories, Andover, MA) in acetonitrile with $0.5 \%$ trifluoroacetic acid. After centrifugation to remove precipitated proteins, $25 \mu \mathrm{l}$ of supernatant was transferred to a microplate and evaporated using warm air. Butanolic $\mathrm{HCl}(50 \mu \mathrm{l}$; Regis Technologies, Morton Grove, IL) was added, and the plate was sealed and heated to $60^{\circ} \mathrm{C}$ for $20 \mathrm{~min}$. The butanolic $\mathrm{HCl}$ was evaporated, and the residue was dissolved in $50 \mu \mathrm{l}$ of $80 \%$ methanol in water. Butylated GABA was quantified using an Applied Biosystems API2000 triple quadrupole mass spectrometer (Applied Biosystems, Foster City, CA) using the TurbolonSpray ionization probe. The butylated GABA $(1 \mu \mathrm{l})$ was injected onto a Supelcosil LC-CN column $(3.3 \times 46 \mathrm{~mm} ; 3 \mu \mathrm{m}$; Supelco, Bellefonte, PA $)$ and eluted with a 0.5 min gradient of $25-95 \%$ solvent $B$ (acetonitrile- $0.2 \%$ formic acid) with solvent A, $0.1 \mathrm{~mm}$ pentadecafluorooctanoic acid in water. The effluent was split 1:5 before entering the mass spectrometer, which was operated in positive ion mode. Data were acquired at unit resolution (width at half-height, 0.7 atomic mass units), monitoring for the 104-87 and 110-93 mass/charge ratio $(\mathrm{m} / \mathrm{z})$ transitions for butylated GABA and $\mathrm{d}_{6}$-GABA, respectively. Nitrogen was used as collision gas at an instrument setting of 6 . All of the mass spectrometer parameters including the orifice and collision voltages were automatically optimized by the Quantitative Optimization feature of the Analyst software using a continuous infusion of $100 \mathrm{~nm}$ butylated GABA. Butylated GABA concentrations were calculated using Analyst software by comparison with a standard curve of identically prepared standards containing 0.10-15 $\mu \mathrm{M}$ GABA in PBS. The limit of quantitation of the assay is $20 \mathrm{~nm}$ with coefficient of variation of $5 \%$.

Data analysis. The speed of migration of five cells, which remained in the plane of focus for the entire duration of the movie, was determined per movie. Analysis was performed blindly. The $x$ and $y$ coordinates of the cell center were measured every $80 \mathrm{sec}$ (corresponding to every eighth frame of 150 frames that constituted each movie). The distance migrated between frames was calculated using the Pythagorean theorem and added to yield the total distance migrated during $25 \mathrm{~min}$. The effects of drugs on the migration rate were calculated by comparing the mean speed of 45 cells under control conditions with that of 45 cells in the same 

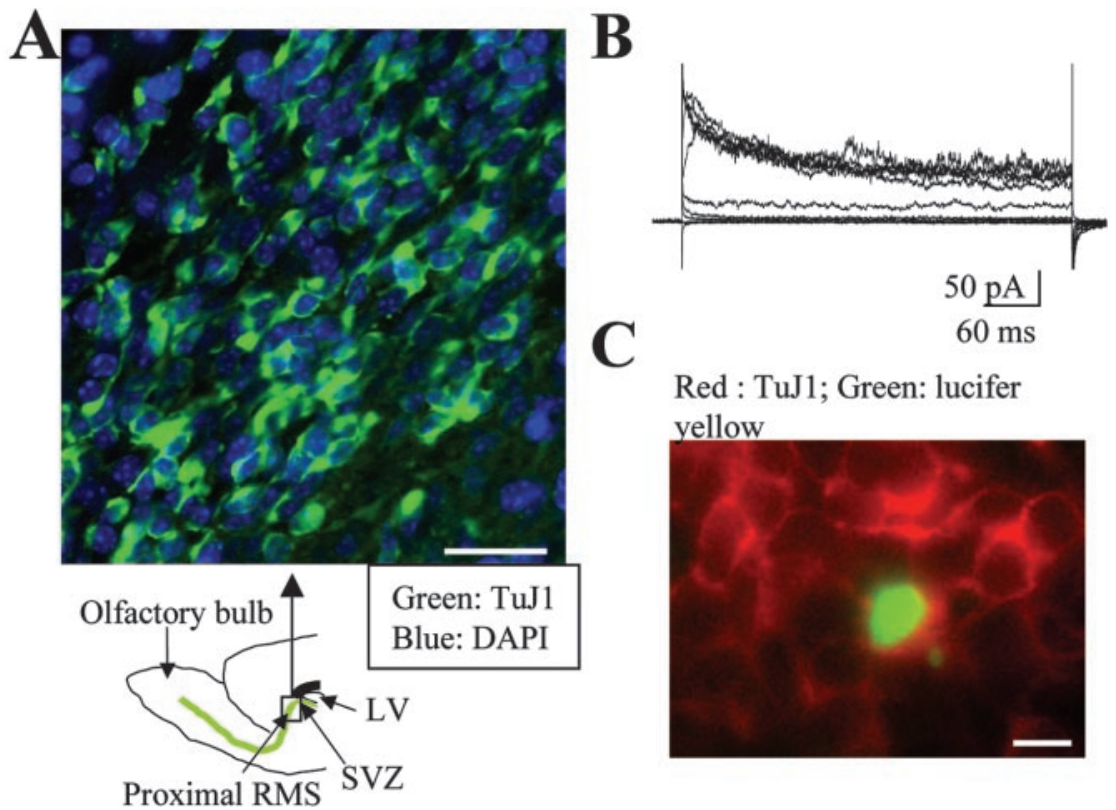

Red : TuJ1; Green: lucifer yellow

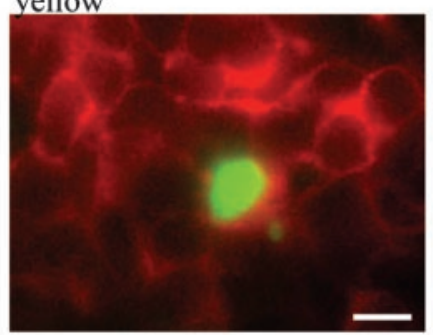

Figure 1. Identification of migrating cells as neuronal precursors. $A$, TuJ1 immunostaining in the anterior SVZ and early RMS of a sagittal slice. A schematic diagram under the photograph illustrates where the photograph was taken. Scale bar, $30 \mu \mathrm{m}$. LV Lateral ventricle. $B, C$, Characteristic outwardly rectifying current traces in response to $20 \mathrm{mV}$ depolarizing pulses from -100 to $+80 \mathrm{mV}(B)$ obtained in the Lucifer yellow-filled cell that stains positive for TuJ1 ( $C$ ). Recorded cells were held at a holding potential of $-70 \mathrm{mV}$. Scale bar, $10 \mu \mathrm{m}$. Staining and recordings were performed in slices from P14-P20 mice.

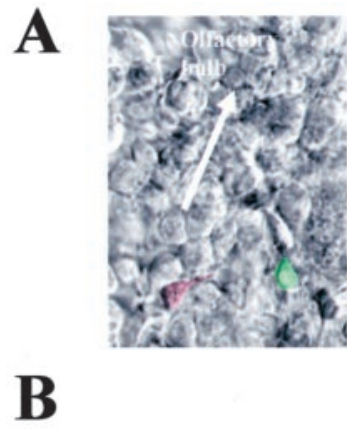

B
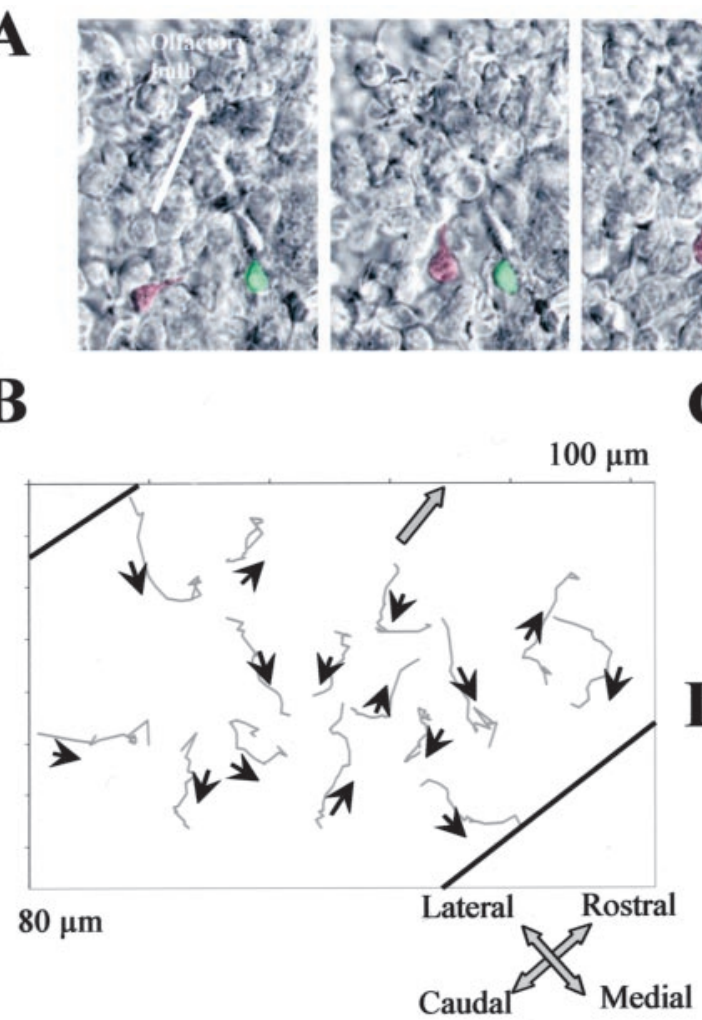
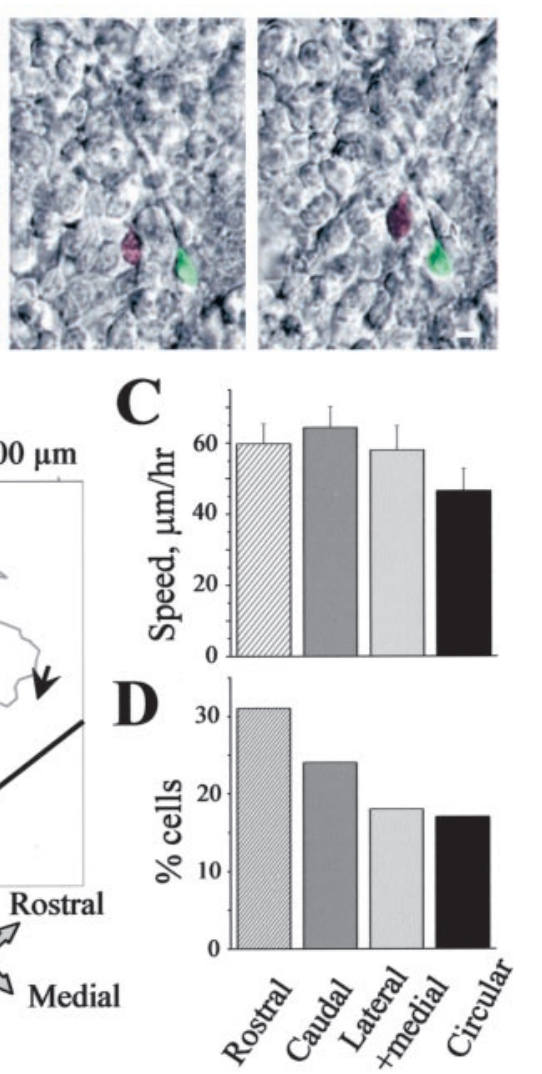

Figure 2. Time-lapse videomicroscopy of neuronal precursors migrating in the SVZ. A, Photographs of migrating cells in the anterior SVZ of an acute sagittal slice from a P17 mouse. A stationary cell is labeled in green and a cell migrating toward the olfactory bulb is labeled in red. Displayed images were taken every $5 \mathrm{~min}$. Scale bar, 50 pixels corresponding to $8 \mu \mathrm{m}$. B, Schematic drawing illustrating the migratory routes of several precursors (arrowheads) in an acute sagittal slice. $C$, Average speed (in micrometers/hour) of cell migration ( $n=45$ cells from three slices from juvenile mice). $D$, Percentage of cells migrating in the different directions illustrated on the drawing in $B$ (same cells as in C). drug-treated slices. Analysis was performed blindly. For electrophysiology, data acquisition, storage, and analysis were performed using pClamp 8.0.2 (Axon Instruments). Data are given as mean \pm SEM, $n$ being the number of cells. Levels of significance were determined by Student's $t$ test on the raw data such as the speed of migration.

\section{Results}

Neuronal precursors are the predominant cell type in the anterior SVZ and RMS

We examined whether cells migrating in the proximal RMS and anterior SVZ (Fig. $1 A$, diagram) from $\mathrm{P} 14-\mathrm{P} 20$ mice were neuronal precursors and not glial precursors (Kakita and Goldman, 1999). Immunostaining for TuJ1 illustrates that the majority of the precursors in the RMS and anterior SVZ are TuJ1 positive (Fig. 1A) and PSA-NCAM positive (supplemental material, available at www.jneurosci.org). PSA-NCAM is another marker of migrating neuronal precursors in the SVZ and RMS (Lois et al., 1996). We randomly recorded cells in acute slices, filled them with Lucifer yellow during recording, and stained them for TuJ1, a marker of neuronal precursors (Doetsch et al., 1997; Luskin, 1998), to determine the biophysical properties and current profile of $\mathrm{TuJ} 1^{+}$cells. $\mathrm{TuJ} 1^{+}$cells displayed uniform biophysical properties characterized by a depolarized resting potential $\left(V_{\mathrm{R}}\right.$ of $-28.4 \pm 2.1 \mathrm{mV}$ measured as the zerocurrent potential; $n=40$ ), a high input resistance $\left(R_{\mathrm{M}}\right.$ of $\left.3.0 \pm 0.7 \mathrm{G} \Omega\right)$, and an outwardly rectifying current profile $(n=$ 6) (Fig. $1 B, C$ ), as previously observed for putative neuronal precursors of the SVZRMS in acute slices (Wang et al., 2003a,b). Furthermore, $96 \%$ (71 of 74 cells; $n=3$ slices) of the recorded cells in the anterior SVZ displayed similar properties and current profile to those of TuJ1 ${ }^{+}$cells. To determine whether migrating cells were neuronal precursors, we recorded migrating cells at $37^{\circ} \mathrm{C}$ and compared their biophysical properties and current profile with those of TuJ $1^{+}$precursors. Migrating cells displayed biophysical properties $\left(V_{\mathrm{R}}\right.$ of $-28.8 \pm 0.4 \mathrm{mV}$ and $R_{\mathrm{M}}$ of $3.4 \pm 0.3 \mathrm{G} \Omega$; $n=3$ ) and an outwardly rectifying current profile identical with those of $\mathrm{TuJ} 1^{+}$neuronal precursors (data not shown).

\section{SVZ precursors move randomly in the} SVZ but in chains in the RMS

We used acute sagittal brain slices to study the migration of neuronal precursors in the anterior SVZ and the RMS of juvenile (postnatal day 14-20) and adult mice (3-4 months of age). The average rate of 
cell migration was similar in juvenile $(51 \pm 1 \mu \mathrm{m} / \mathrm{hr} ; n=270$ cells; 18 slices; mean \pm SEM) and adult mouse SVZ (47 \pm 2 $\mu \mathrm{m} / \mathrm{hr} ; n=90$ cells; six slices). The rate of cell migration was determined by measuring the distance traveled every $80 \mathrm{sec}$ during 25 min using time-lapse videomicroscopy (see Materials and Methods). Migrating cells extended a leading process toward the direction of migration, as previously reported for SVZ and cerebellar neuronal precursors (Komuro and Rakic, 1996; Wichterle et al., 1997; Murase and Horwitz, 2002; Suzuki and Goldman, 2003) (Fig. 2A) (supplemental material, available at www. jneurosci.org). Although SVZ neuronal precursors are destined for the olfactory bulb and follow chain migration (Luskin, 1993; Lois and Alvarez-Buylla, 1994; Lois et al., 1996), they displayed various directions of migration in the SVZ and proximal RMS of juvenile mice as shown in Figure 2 B. Only 34\% of the precursors migrated toward the olfactory bulb (rostral direction). Furthermore, although the majority (61\%) of the SVZ neuronal precursors migrated in the direction of the "chains" (rostral and caudal directions), 20\% changed chains (lateral and medial directions) and $19 \%$ displayed a circular migration ( $n=45$ cells; three slices) (Fig. 2C). These characteristics were routinely observed deep inside the slice (four to five layers deep), where the environment is well preserved, as well as at the surface of the slice. Chain-like architecture was visible in the RMS of the olfactory bulb where $80 \%$ of the precursors migrated toward the olfactory bulb (compared with 34\% in the SVZ; data not shown). Because we found no correlation between the speed and the direction of migration (Fig. 2D) and because GABAergic drugs such as GABA and bicuculline affected the migration speed independently of the direction of migration, data regarding the speed of cell migration under different experimental conditions were pooled independent of the direction of migration.

Ambient GABA tonically reduces the speed of neuronal precursor migration by activating $\mathrm{GABA}_{\mathrm{A}} \mathrm{Rs}$

We previously reported that putative neuronal precursors of the SVZ-RMS express GABA ${ }_{A}$ Rs in acute slices (Wang et al., 2003a). However, it remains unknown whether endogenous GABA exerts a tonic influence on the speed of neuronal precursor migration. All of the following experiments, unless otherwise noted, were performed in P14-P20 mice. Application of $10 \mu \mathrm{M}$ GABA significantly reduced the speed of neuronal precursor migration by $23 \%$ in acute slices from postnatal day 14-20 mice [ from $57 \pm$ 3 to $44 \pm 3 \mu \mathrm{m} / \mathrm{hr} ; n=90$ cells ( 45 cells per control and 45 cells with GABA) from three slices; $p<0.001$ ] (Fig. $3 A$ ). For all of the migration experiments, the migration speeds of 90 cells ( 45 cells per control and 45 cells with a drug) from three slices were routinely measured per condition. We applied GABA at $10 \mu \mathrm{M}$, because this concentration is lower than the $\mathrm{EC}_{50}$ value for $\mathrm{GABA}_{\mathrm{A}}$ Rs in cultured neuronal precursors (Stewart et al., 2002), and applications of $10 \mu \mathrm{M}$ GABA did not completely desensitize $\mathrm{GABA}_{\mathrm{A}} \mathrm{Rs}$ in neuronal precursors (Fig. $3 B$ ). For these experiments, GABA was pressure applied for $16.5 \mathrm{~min}$ onto neuronal precursors recorded in voltage clamp at a holding potential of $-70 \mathrm{mV}$ in acute SVZ slices. GABA can activate both ionotropic $\mathrm{GABA}_{\mathrm{A}}$ and $\mathrm{GABA}_{\mathrm{C}} \mathrm{Rs}$, as well as G-protein-coupled $\mathrm{GABA}_{\mathrm{B}} \mathrm{Rs}$ (Chebib and Johnston, 1999). The effect of GABA was mediated by the activation of $\mathrm{GABA}_{\mathrm{A}} \mathrm{Rs}$, because applications of $10 \mu \mathrm{M}$ $\mathrm{GABA}$ in the presence of the $\mathrm{GABA}_{\mathrm{A}} \mathrm{R}$ antagonist bicuculline (100 $\mu \mathrm{M}$; the control is in the presence of bicuculline) or applications of the $\mathrm{GABA}_{\mathrm{B}} \mathrm{R}$ agonist baclofen $(10 \mu \mathrm{M})$ did not affect the speed of cell migration ( $p>0.1$ in each case; $n=45$ cells from three slices per condition) (Fig. 3A). Furthermore, application of

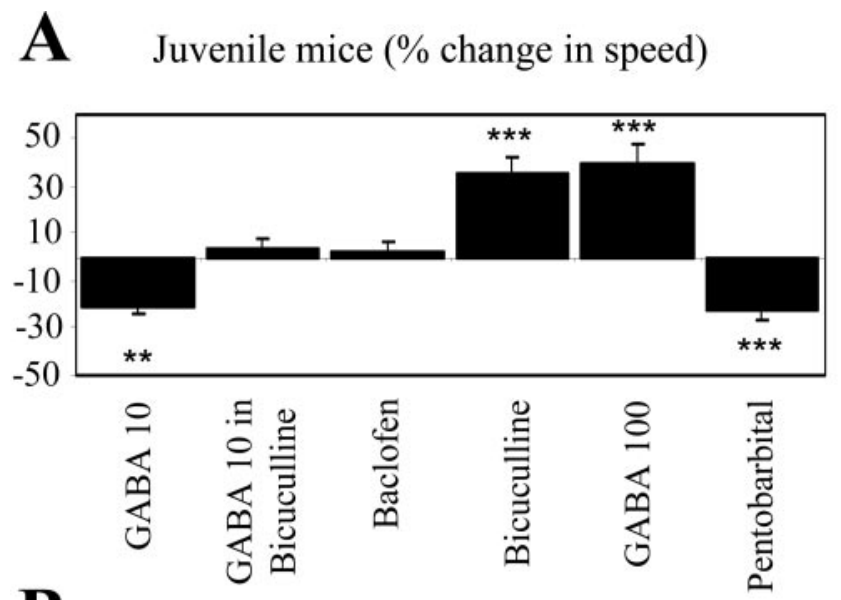

B

$10 \mu \mathrm{M} \mathrm{GABA}$

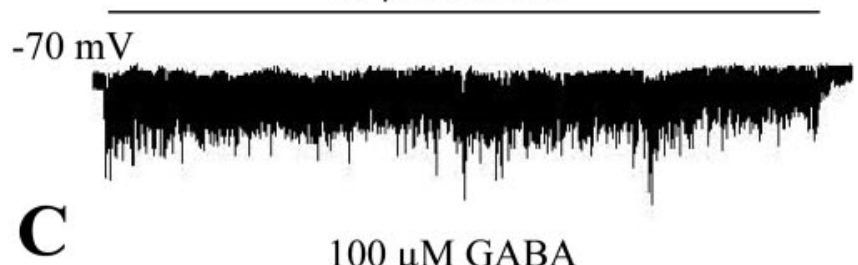

$-70 \mathrm{mV}$

$100 \mu \mathrm{M}$ GABA

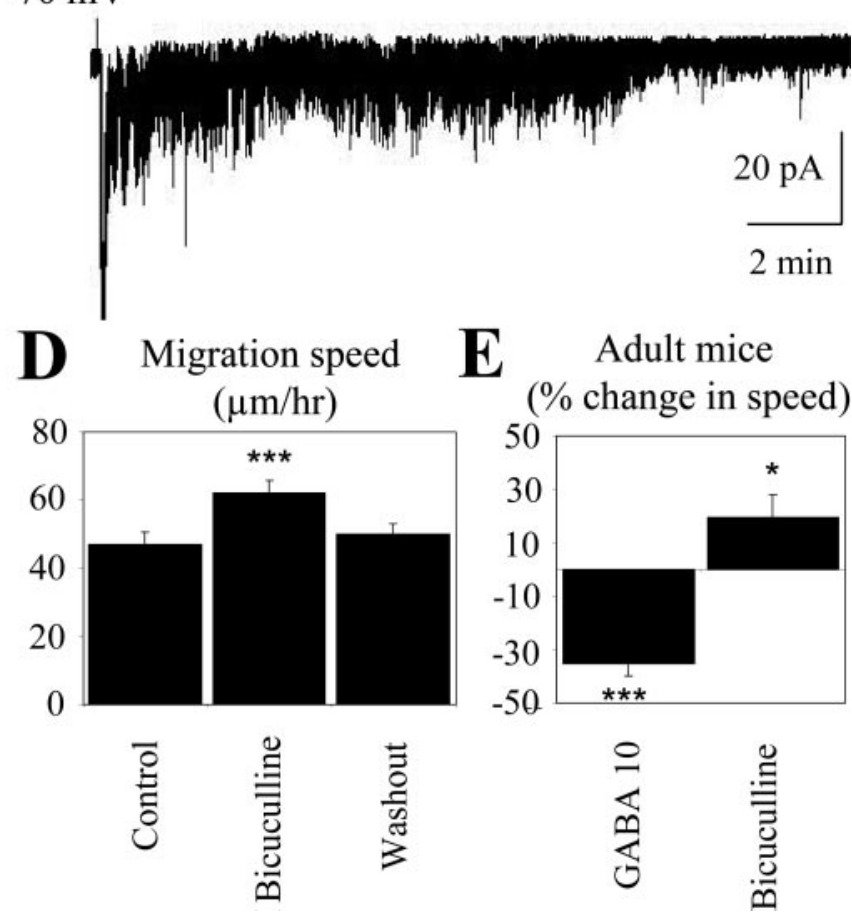

Figure 3. Ambient $G A B A$ reduces the speed of neuronal precursor migration via $G A B A_{A} R$ activation. $A$, Average percentage change in the speed of neuronal precursor migration induced by applications of various drugs: $10 \mu \mathrm{m} G A B A, G A B A$ in the presence of $100 \mu \mathrm{m}$ bicuculline, $10 \mu \mathrm{m}$ baclofen (a GABA${ }_{B} R$ agonist), $100 \mu \mathrm{m}$ bicuculline, $100 \mu \mathrm{m}$ $\mathrm{GABA}$, or $50 \mu \mathrm{m}$ pentobarbital (a $\mathrm{GABA}_{\mathrm{A}} \mathrm{R}$ allosteric enhancer) in juvenile mice. $B, C$, Inward $G_{A B A_{A}}$ currents in neuronal precursors induced by pressure applications of $10(B)$ and $100 \mu \mathrm{M}$ ( $C$ ) GABA (as indicated by the bar above the trace). Cells were recorded at a holding potential of $-70 \mathrm{mV}$ in acute slices from juvenile mice. D, Average speed (in micrometers/hour) of cell migration in slices from juvenile mice under control, during bicuculline application, and after washout of bicuculline. $E$, Average percentage change in the speed of neuronal precursor migration induced by $10 \mu \mathrm{m}$ GABA and by $100 \mu \mathrm{m}$ bicuculline on the speed of neuronal precursor migration rate in adult mice (3-4 months of age). The migration speeds of 90 cells ( 45 cells in control and 45 cells with a drug) from three slices were routinely measured per condition. ${ }^{* *} p<0.01 ;{ }^{* * *} p<0.001$. 
A

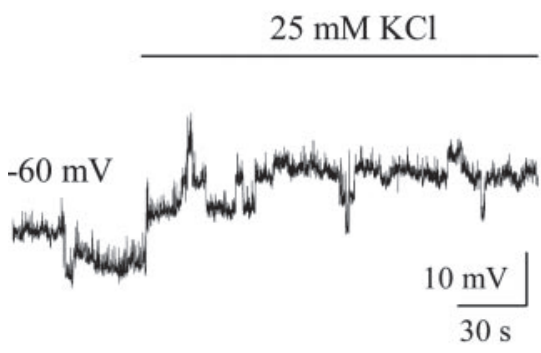

C

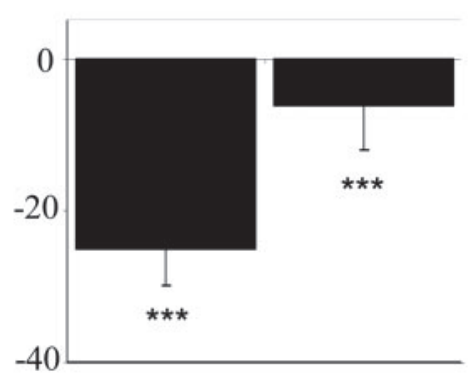

$25 \mathrm{mM} \mathrm{KCl} 25 \mathrm{mM} \mathrm{KCl}$ in bicuculline

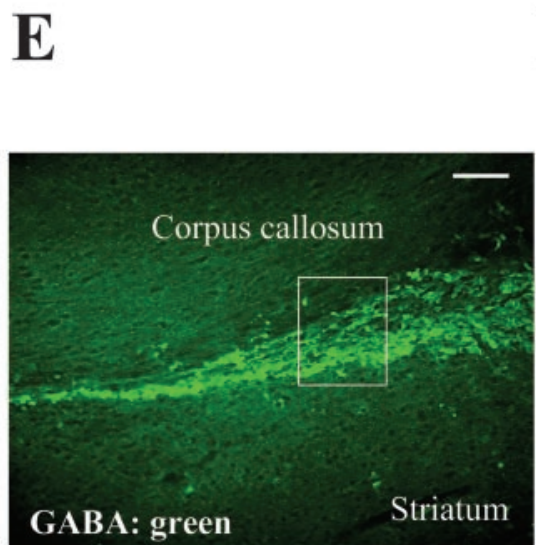

B GABA levels $(\mu \mathrm{M})$

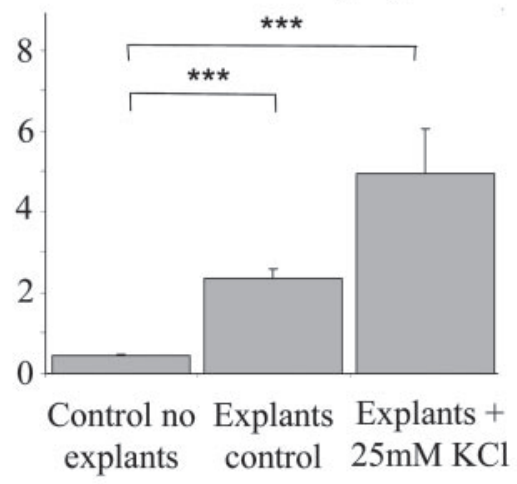

D

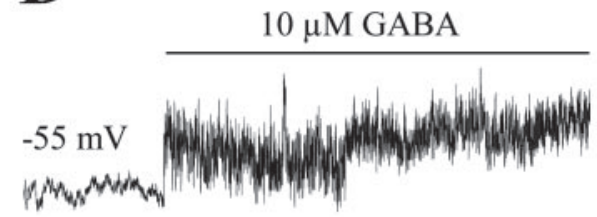

$25 \mathrm{mM} \mathrm{KCl}$ with bicuculline

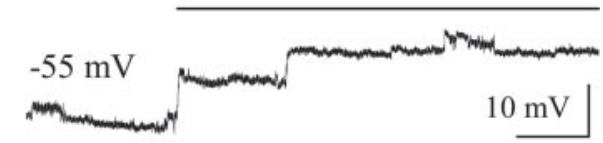

$30 \mathrm{~s}$

$\mathbf{F}$

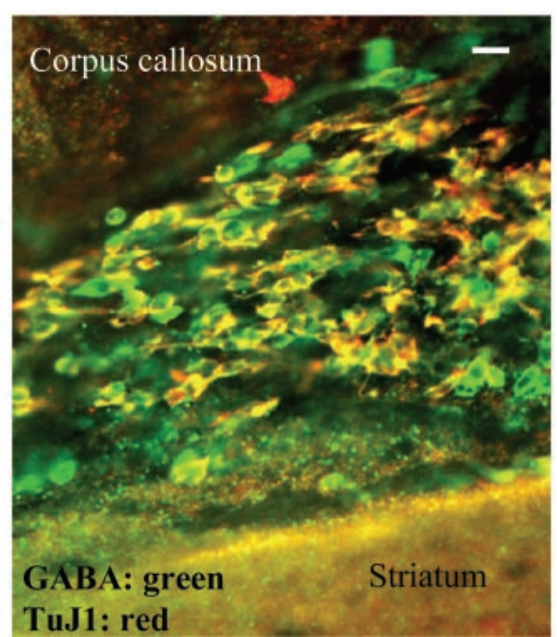

Figure 4. Depolarization-induced GABA release reduces the speed of cell migration via $G_{A B A} R$ activation. $A$, Depolarization induced by a pressure application of $25 \mathrm{~mm} \mathrm{~K}^{+}$in neuronal precursors recorded in the current-clamp configuration. $B$, Mean concentration of GABA in the BME solution and in the supernatant $(20 \mu \mathrm{l})$ of four explants under control and during $25 \mathrm{~mm} \mathrm{~K}^{+}$ application for $1 \mathrm{hr}$. C, Average percentage change in the speed of neuronal precursor migration induced by $25 \mathrm{~mm} \mathrm{~K}^{+}$applications with and without $100 \mu \mathrm{m}$ bicuculline. The migration speeds of 90 cells ( 45 cells in control and 45 cells with a drug) from three slices were routinely measured per condition. $D$, Depolarizations induced by pressure application of $25 \mathrm{~mm} \mathrm{~K}{ }^{+}$in the presence of bicuculline or $10 \mu \mathrm{MGABA}$ in neuronal precursors recorded in the current-clamp configuration. Neuronal precursors were recorded with an intracellular solution containing $29 \mathrm{~mm} \mathrm{Cl}^{-}$. E, GABA immunostaining (green) within the SVZ and RMS in a sagittal slice. The rectangle indicates the location of the photograph displayed in $F$. Scale bar, $100 \mu \mathrm{m}$. F, GABA (green) and TuJ1 (red) immunostainings in a sagittal slice. Immunostaining was performed in a different slice than that used for the staining shown in $E$. Scale bar, $10 \mu \mathrm{m}$. Experiments were performed in acute slices and RMS explants from P14-P20 mice. ${ }^{* * *} p<0.001$.

bicuculline $(50-100 \mu \mathrm{M})$ increased the speed of cell migration by $35 \%$ (from $45 \pm$ 3 to $61 \pm 3 \mu \mathrm{m} / \mathrm{hr} ; p<0.001$ ) (Fig. $3 A$ ), suggesting that there is sufficient ambient GABA surrounding SVZ precursors to tonically activate $\mathrm{GABA}_{\mathrm{A}} \mathrm{Rs}$ and reduce the speed of neuronal precursor migration. The action of bicuculline $(50 \mu \mathrm{M})$ on cell migration was reversible, as displayed in Figure 3C. Consistent with a tonic activation of $\mathrm{GABA}_{\mathrm{A}} \mathrm{Rs}$, the allosteric enhancer of $\mathrm{GABA}_{\mathrm{A}} \mathrm{R}$-mediated responses in neuronal precursors, pentobarbital (50 $\mu \mathrm{M}$ ) (Wang et al., 2003a), significantly decreased the speed of cell migration by $36 \%$ (from $49 \pm 2$ to $38 \pm 2 \mu \mathrm{m} / \mathrm{hr} ; p<0.001$ ) (Fig. 3A). Application of a desensitizing concentration of GABA $(100 \mu \mathrm{M})$ had an opposite effect to that of $10 \mu \mathrm{M}$ GABA, resulting in a $39 \%$ increase in the speed of cell migration (from $42 \pm 2$ to $59 \pm 3$ $\mu \mathrm{m} / \mathrm{hr} ; p<0.001$ ) (Fig. $3 A$ ). During voltage-clamp recordings of neuronal precursors, pressure application of $100 \mu \mathrm{M}$ GABA induced a complete desensitization of $\mathrm{GABA}_{\mathrm{A}} \mathrm{Rs}$, because GABA-induced currents returned to baseline when GABA was still present (Fig. $3 B$ ). These data suggest that $\mathrm{GABA}_{\mathrm{A}} \mathrm{R}$ desensitization with $100 \mu \mathrm{M}$ GABA relieved the tonic decrease exerted by ambient GABA on the speed of cell migration, resulting in an enhancement of the migration speed. As observed in juvenile mice, $10 \mu \mathrm{M}$ GABA and $100 \mu \mathrm{M}$ bicuculline applied in slices from adult mice significantly reduced and increased the speed of migration by $35 \%$ (from $50 \pm$ 3 to $33 \pm 2 \mu \mathrm{m} / \mathrm{hr}$ ) and $19 \%$ (from $44 \pm 2$ to $53 \pm 3 \mu \mathrm{m} / \mathrm{hr} ; p<0.001$ in each case) (Fig. $3 D$ ), respectively. Interestingly, the effects of GABA on the migration speed was significantly different in young and adult animals $(p<0.01)$. However, the effect of bicuculline on the migration speed was not significantly different between young and old animals, although bicuculline tended to increase the migration speed more in juvenile animals (35\%) than in old animals (19\%). Although these data suggest that the influence of endogenous GABA on cell migration may change during postnatal development, a large number of additional experiments performed at different ages would be required to conclude on such a developmental change.

Depolarization-induced GABA release reduces the speed of neuronal precursor migration via $\mathrm{GABA}_{\mathrm{A}} \mathrm{R}$ activation

Tonic $\mathrm{GABA}_{\mathrm{A}} \mathrm{R}$ activation in neuronal precursors and positive GABA immunostaining in RMS and SVZ cells (Wang et al., 2003a) suggest that RMS and SVZ cells 
release GABA. We thus tested in acute slices from P14-P20 mice whether depolarization of precursors with high $\mathrm{K}^{+}$enhanced GABA release and affected the speed of cell migration. Pressure or bath application of $25 \mathrm{~mm} \mathrm{~K}^{+}$depolarized neuronal precursors by $15-20 \mathrm{mV}(n=3)$ (Fig. $4 A)$. Neuronal precursors were recorded at a membrane potential of -55 to $-60 \mathrm{mV}$, which is the estimated actual resting potential of these cells (Wang et al., 2003a,b). KCl at $25 \mathrm{~mm}$ induced a $\sim 2.5$-fold increase in GABA concentration, measured in the supernatant of proximal RMS explants using mass spectrometry (from $\sim 2 \mu \mathrm{M}$ in control to $5 \mu \mathrm{M}$ with high $\mathrm{K}^{+} ; n=3$ ) (Fig. $4 B$ ). These data suggest that GABA is tonically released from precursors in RMS explants, and that extracellular GABA levels can be increased by high $\mathrm{K}^{+}$application. Consistent with this result, application of $25 \mathrm{~mm}$ $\mathrm{KCl}$ significantly reduced the speed of cell migration by $38 \%$ (from $47 \pm 2$ to $36 \pm 2$ $\mu \mathrm{m} / \mathrm{hr} ; p<0.001$ ) (Fig. $4 C$ ). Furthermore, when tested in the presence of the $\mathrm{GABA}_{\mathrm{A}} \mathrm{R}$ blocker bicuculline $(100 \mu \mathrm{M})$, high $\mathrm{K}^{+}$did not alter the speed of neuronal precursor migration (from $54 \pm 3$ to $50 \pm 3 \mu \mathrm{m} / \mathrm{hr}$; $p>0.1$ ) (Fig. 4C), suggesting that an increase in extracellular GABA levels, but not cell depolarization per se, affected the speed of cell migration. Cell depolarization by GABA has been proposed previously as an intrinsic mechanism to regulate the speed of cell migration (Barker et al., 1998), and 25 $\mathrm{mM} \mathrm{K}^{+}$in the presence of bicuculline still depolarized SVZ neuronal precursors by $10-15 \mathrm{mV}(n=3)$, which is similar to the depolarization induced by $10 \mu \mathrm{M}$ GABA when cells were recorded with an intracellular solution containing a near-physiological $\mathrm{Cl}^{-}$concentration $(29 \mathrm{~mm} ; n=3$ ) (Wang et al., 2003a) (Fig. 4D). Finally, to determine whether neuronal precursors are a source of GABA, coimmunostaining for GABA and $\mathrm{TuJ} 1$ was performed on sagittal slices. GABA was present in the cytoplasm of most cells in the SVZ and RMS (Fig. 4E) and essentially in all of the TuJ1 ${ }^{+}$cells in the SVZ (Fig. 4F) and RMS (data not shown). Collectively, these data suggest that high $\mathrm{K}^{+}$reduces the speed of neuronal precursor migration by enhancing GABA release from neuronal precursors and autocrineparacrine $\mathrm{GABA}_{\mathrm{A}} \mathrm{R}$ activation.

\section{Inhibition of GABA uptake into}

astrocyte-like cells reduces the speed of neuronal precursor migration via $\mathrm{GABA}_{\mathrm{A}} \mathrm{R}$ activation

Because astrocyte-like cells ensheath chains of GABA-containing neuronal precursors, we examined whether astrocyte-like cells express GABA uptake systems. Among the four subtypes of highaffinity GABA transporters expressed in the mouse brain, GAT1 ${ }^{* * *} p<0.001$.

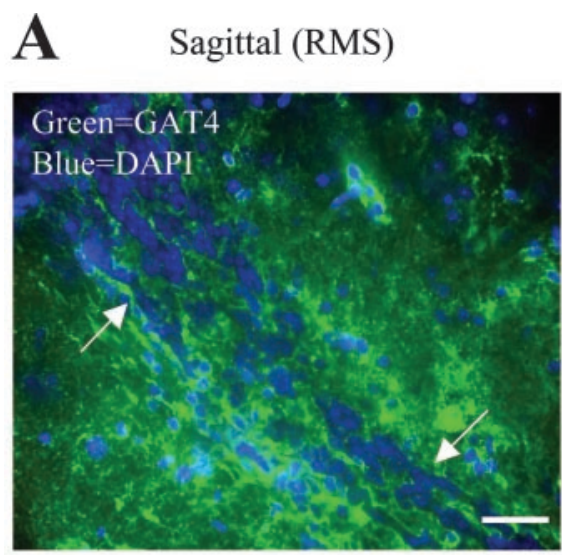

B Coronal (RMS)
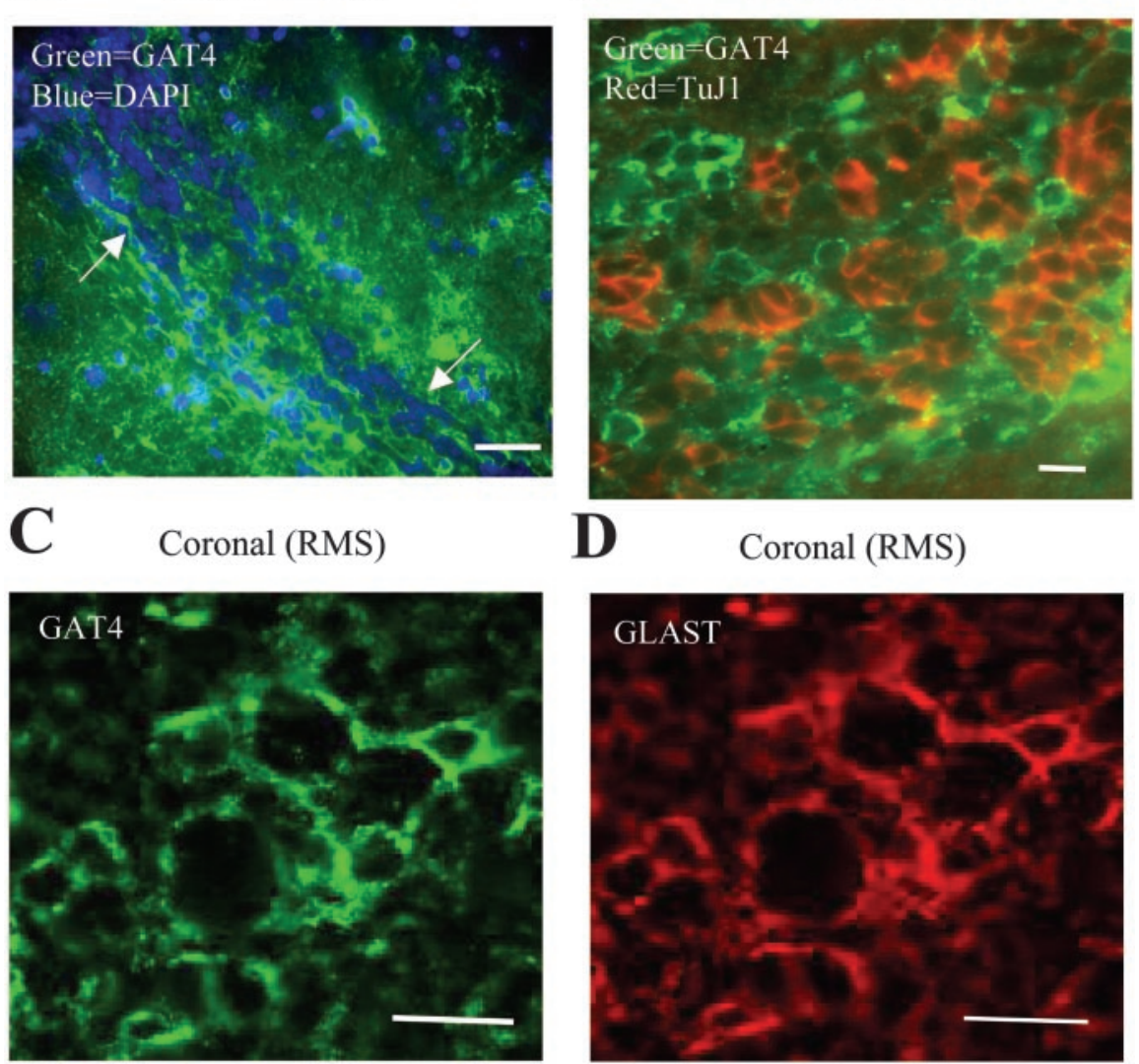

D

Coronal (RMS)
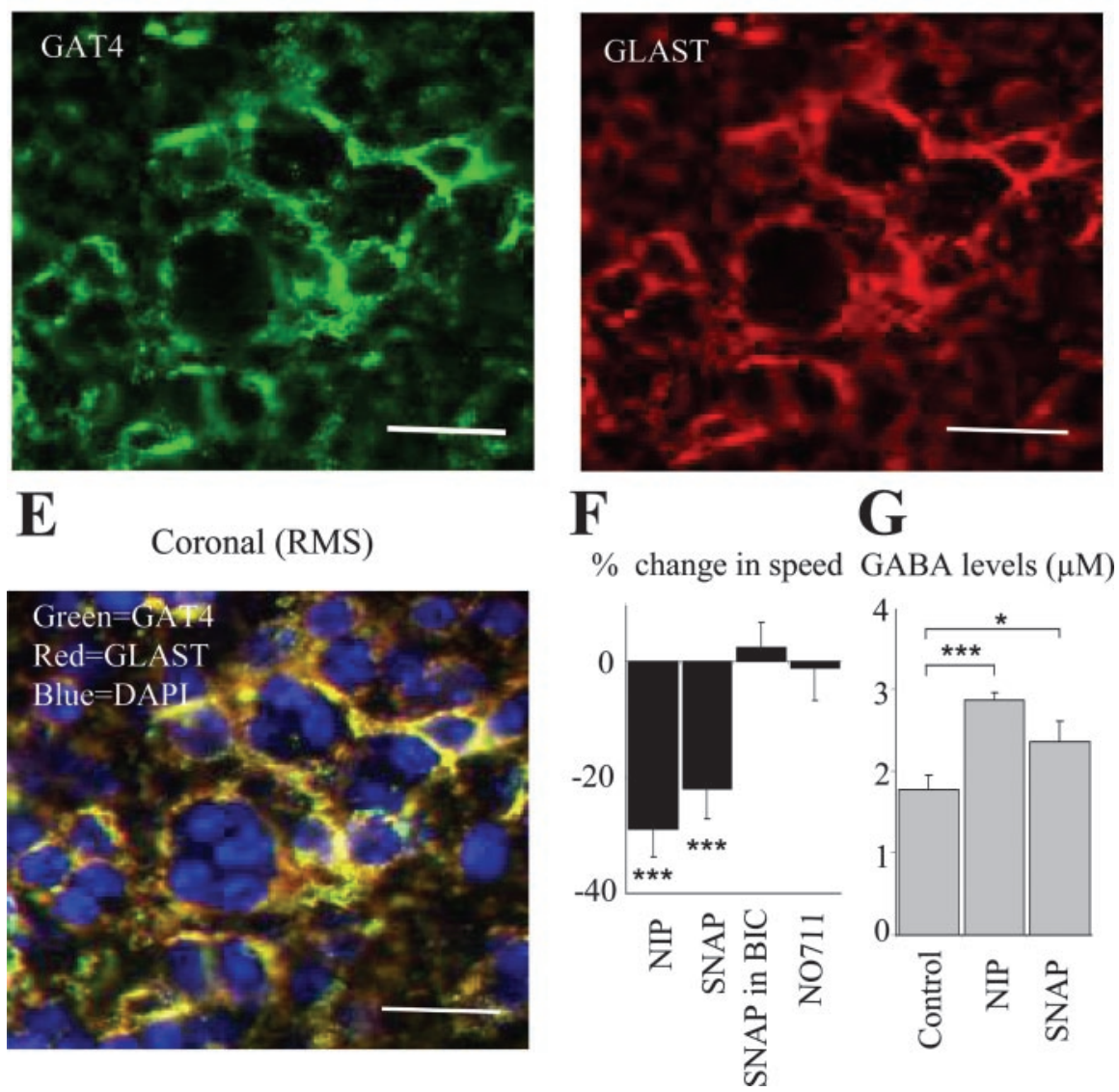

Figure 5. GABA uptake into astrocyte-like cells controls the speed of neuronal progenitor migration. $A$, Coimmunostaining for GAT4 (green; rat GAT-3) and DAPI (blue) in the anterior SVZ of a sagittal slice. Note the chains of precursors ensheathed by GAT4 ${ }^{+}$ cells (arrows). Scale bar, $50 \mu \mathrm{m}$. B, Coimmunostaining for GAT4 (green) and TuJ1 (red) in the anterior SVZ in a coronal slice. C, D, Immunostainings for GAT4 ( $C$, green) and GLAST $(D$, red) in the RMS of a coronal slice. $E$, Superimposition of the immunostainings for GAT4 (green), GLAST (red), and DAPI (blue) from slices shown in (and D. Scale bars: $B-E, 20 \mu \mathrm{m}$. F, Average percentage decrease in the speed of neuronal precursor migration induced by $100 \mu \mathrm{m}$ nipecotic acid (NIP) or $50 \mu \mathrm{M}$ SNAP5114 (SNAP). BIC, Bicuculline. The migration speeds of 90 cells ( 45 cells in control and 45 cells with a drug) from three slices were routinely measured per condition. $G$, Mean concentration of GABA in the supernatant ( $20 \mu \mathrm{l}$ ) of four explants under control, in the presence of $100 \mu \mathrm{M}$ nipecotic acid, or $50 \mu \mathrm{m}$ SNAP5114. Experiments were performed in acute slices and explants from P14-P20 mice. ${ }^{*} p<0.01$;

and GAT4 (rat GAT-1 and GAT-3, respectively) are highly expressed in neurons and astrocytes, respectively (Borden, 1996). GAT1 immunostaining was not detected in the SVZ or RMS (data not shown). However, GAT4 immunostaining was observed in SVZ cells encapsulating chains of precursors in sagittal 
slices (Fig. 5A). To determine which SVZ cells express GAT4, we performed coimmunostaining for GAT4 and the neuronal precursor marker TuJ1 or the glutamate transporter GLAST, which is expressed in radial glia (Shibata et al., 1997) and astrocytes (Rothstein et al., 1994; Lehre et al., 1995). GAT4 (green) and TuJ1 (red) immunostainings were mutually exclusive (Fig. 5B). GAT4 (green) was exclusively expressed in GLAST $^{+}$cells (red) that surrounded clusters of DAPI ${ }^{+}$precursors (Fig. $5 C$ ), indicating that GAT4 is expressed in astrocyte-like cells but not in neuronal precursors. We also found that every cell expressing GLAST expresses GAT4 in both juvenile and adult SVZ or RMS (Fig. 5C) (supplemental material, available at www.jneurosci.org). We then examined the effect of nipecotic acid $(100 \mu \mathrm{M})$, the transportable competitive blocker of GAT1, GAT3, and GAT4, on the speed of neuronal precursor migration. Application of nipecotic acid significantly decreased the speed of cell migration by $34 \%$ (from $53 \pm 3$ to $38 \pm 2 \mu \mathrm{m} / \mathrm{hr} ; p<0.001$ ) (Fig. $5 \mathrm{C}$ ). Consistent with the immunostaining data, the nontransportable antagonist of GAT1, NO711 (10 $\mu \mathrm{M})$, did not significantly affect the speed of cell migration $(p>0.05)$ (Fig. $5 C$ ), whereas the nontransportable antagonist of GAT3 and -4, SNAP5114 (50 $\mu \mathrm{M})$, significantly reduced the speed of cell migration by $24 \%$ (from $54 \pm 3$ to $43 \pm$ $3 \mu \mathrm{m} / \mathrm{hr} ; p<0.01)$. Furthermore, the effect of SNAP5114 on cell migration was prevented when the $\mathrm{GABA}_{\mathrm{A}} \mathrm{R}$ blocker bicuculline $(100 \mu \mathrm{M})$ was included in the bath solution (Fig. $5 C$, the control is with bicuculline). Consistent with these migration data, nipecotic acid and SNAP5114 induced a 60 and 30\% increase of GABA levels in the supernatant of acute explants, respectively (from 1.8 to $2.9 \mu \mathrm{M}$ with nipecotic acid and $2.4 \mu \mathrm{M}$ with SNAP5114) (Fig. 5C). These data suggest that GABA uptake into astrocyte-like cells enhances the speed of neuronal precursor migration by clearing GABA released into the extracellular space and limiting $\mathrm{GABA}_{\mathrm{A}} \mathrm{R}$ activation in neuronal precursors.

\section{Ambient GABA reduces the speed of neuronal precursor migration by interfering with intracellular \\ $\mathrm{Ca}^{2+}$ signaling}

Because intracellular $\mathrm{Ca}^{2+}$ signaling is involved in regulating cell migration (Komuro and Rakic, 1998), we examined in slices from juvenile mice whether GABA reduced the speed of neuronal precursor migration by interfering with intracellular $\mathrm{Ca}^{2+}$ signaling. Bath application of $1 \mathrm{~mm}$ EGTA to decrease extracellular $\left[\mathrm{Ca}^{2+}\right]$ or incubation of slices with $10 \mu \mathrm{M}$ BAPTA-AM to clamp intracellular $\left[\mathrm{Ca}^{2+}\right]$ to low levels significantly reduced the speed of cell migration by $45 \%$ (from $43 \pm 2$ to $24 \pm 2 \mu \mathrm{m} / \mathrm{hr}$ ) and $55 \%$ $(70.0 \pm 3.3$ to $31.6 \pm 2.5 \mu \mathrm{m} / \mathrm{hr}$; the control was in pluronic acid), respectively $\left(p<0.001\right.$ ) (Fig. 6A). Blockade of $\mathrm{Ca}^{2+}$ release from inositol 1,4,5-trisphosphate $\left(\mathrm{IP}_{3}\right)$-sensitive $\mathrm{Ca}^{2+}$ stores with 2-aminoethoxydiphenyl borate (2-APB) $(100 \mu \mathrm{M})$ significantly reduced the speed of neuronal precursor migration by $25 \%$ (from $50 \pm 4$ to $38 \pm 3 \mu \mathrm{m} / \mathrm{hr} ; p<0.01$ ) (Fig. $6 A$ ), suggesting that $\mathrm{Ca}^{2+}$ release from $\mathrm{IP}_{3}$-sensitive $\mathrm{Ca}^{2+}$ stores is involved in regulating the speed of neuronal precursor migration. Consistent with the lack of effect of cell depolarization per se on the speed of migration, inhibition of voltage-gated $\mathrm{Ca}^{2+}$ channels with 30-100 $\mu \mathrm{M} \mathrm{Ni}^{2+}$ and $100 \mu \mathrm{M} \mathrm{Cd}{ }^{2+}$ (Hille, 1992) did not block the effect of GABA on cell migration (Fig. $6 \mathrm{~B}$, the control is in the presence of $\mathrm{Ni}^{2+}$ and $\mathrm{Cd}^{2+}$ ). In the presence of 2-APB, GABA or bicuculline had no effect on the speed of neuronal precursor migration (Fig. $6 B$, the controls are in the presence of 2-APB), suggesting that GABA and $G_{A B A} R$ activation reduce the speed of cell migration by interfering with $\mathrm{Ca}^{2+}$ release from intracellular $\mathrm{Ca}^{2+}$ stores.
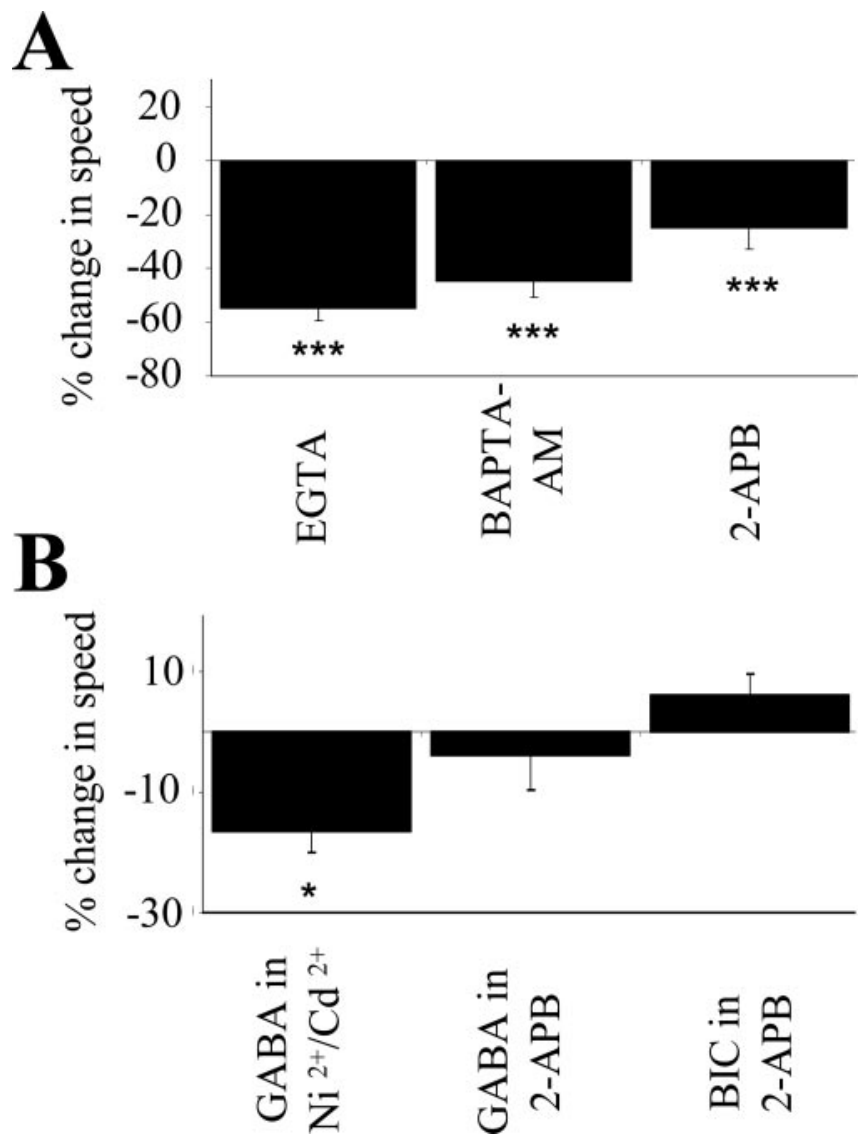

Figure 6. $G_{A B A_{A}} R$ activation reduces the speed of neuronal precursor migration by interfering with $\mathrm{Ca}^{2+}$ release from intracellular $\mathrm{Ca}^{2+}$ stores. $A$, Average percentage decrease in the speed of neuronal precursor migration induced by $1 \mathrm{~mm}$ EGTA, $10 \mu \mathrm{m}$ BAPTA-AM, or $100 \mu \mathrm{m}$ $2-A P B .{ }^{* *} p<0.001$. $B$, Average percentage change in the speed of neuronal precursor migration induced by $10 \mu \mathrm{m}$ GABA or bicuculline (BIC) in the presence of $100 \mu \mathrm{m} 2-A \mathrm{~PB}$. The control speed of migration was measured in the presence of 2-APB. The migration speeds of 90 cells (45 cells in control and 45 cells with a drug) in three slices from juvenile mice were routinely measured per condition. ${ }^{*} p<0.05$.

\section{Discussion}

We show here that ambient GABA reduces the speed of cell migration independently of cell depolarization by interfering with $\mathrm{Ca}^{2+}$ release from intracellular $\mathrm{Ca}^{2+}$ stores. Furthermore, we found that astrocyte-like cells strongly influence the migration of postnatal SVZ and RMS neuronal precursors by tightly regulating ambient GABA levels and thus the degree of $\mathrm{GABA}_{\mathrm{A}} \mathrm{R}$ occupancy in neuronal precursors.

\section{Characteristics of neuronal precursor migration in the anterior SVZ and RMS}

This study shows that migrating cells in the SVZ-RMS are predominantly neuronal and not glial precursors based on their biophysical properties, current profile, and positive immunostaining for TuJ1 and PSA-NCAM. It was also recently reported that TuJ1-positive cells in the SVZ and RMS stain positive for doublecortin, an additional neuronal precursor marker (Yang et al., 2004). The exclusive presence of neuronal precursors in the anterior SVZ and RMS is consistent with the time course of gliogenesis that ceases at $\sim 14-15 \mathrm{~d}$ of age in rats (Levison and Goldman, 1993). This is the first report that unambiguously identifies the biophysical properties and current profile of $\mathrm{TuJ} 1^{+}$precursors in acute slices. The averaged speed of neuronal precursor migration 
( $\sim 50 \mu \mathrm{m} / \mathrm{hr}$ ) is slower than that in SVZ explants $(100 \mu \mathrm{m} / \mathrm{hr})$ (Wichterle et al., 1997) but faster than that reported in vivo $(25 \mu \mathrm{m} /$ hr) (Lois and Alvarez-Buylla, 1994). Cells migrating in slices encounter more physical constraints than cells leaving explants, but in slices, the level of signaling molecules, such as GABA, that reduce the migration speed is likely lower than that in vivo. Although the speed of cell migration was similar in the SVZ and RMS, fewer neuronal precursors followed chain migration in the SVZ (34\%) than in the RMS of the olfactory bulb (80\%). A larger number of intersecting and dead-end chains in the SVZ (Doetsch and Alvarez-Buylla, 1996) may explain a more disorganized direction of traffic in the SVZ compared with that in the RMS. Alternatively, newly generated precursors in the SVZ may be searching for directional cues before entering the RMS, suggesting that SVZ neuronal precursors could be redirected by adding exogenous cues, such as tenascin-R (Saghatelyan et al., 2004).

\section{GABA release from neuronal precursors and uptake into astrocyte-like cells regulates the speed of neuronal precursor migration via $\mathrm{GABA}_{\mathrm{A}} \mathrm{R}$ activation}

GABA application reduced the speed of cell migration via $\mathrm{GABA}_{\mathrm{A}} \mathrm{R}$ but not $\mathrm{GABA}_{\mathrm{B}} \mathrm{R}$ activation, because bicuculline could block the effect but a $\mathrm{GABA}_{\mathrm{B}} \mathrm{R}$ agonist did not alter cell migration. $\mathrm{GABA}_{\mathrm{A}} \mathrm{R}$ activation is thought to affect the speed of embryonic neuron migration via its depolarizing action (Barker et al., 1998; Fueshko et al., 1998). We showed previously that $\mathrm{GABA}_{\mathrm{A}} \mathrm{R}$ activation depolarizes SVZ neuronal precursors (Wang et al., 2003a), and we also found that application of high $\mathrm{K}^{+}$reduces the speed of neuronal precursor migration. However, depolarization of SVZ neuronal precursors with high $\mathrm{K}^{+}$in the presence of bicuculline did not alter the speed of cell migration, suggesting that GABA alters cell migration through a novel mechanism independent of cell depolarization. Our study also shows that ambient GABA tonically decreases the speed of cell migration via $\mathrm{GABA}_{\mathrm{A}} \mathrm{R}$ activation, because bicuculline increased whereas pentobarbital decreased the speed of migration. Tonic $\mathrm{GABA}_{\mathrm{A}} \mathrm{R}$ activation and GABA accumulation in the supernatant of RMS explants strongly suggest that GABA is tonically released from SVZ precursors. Furthermore, depolarizing SVZ precursors with high $\mathrm{K}^{+}$significantly enhanced GABA release and decreased the speed of cell migration via $\mathrm{GABA}_{\mathrm{A}} \mathrm{R}$ activation. Among SVZ cells, the neuronal precursors are the likely source of GABA, because most of the SVZ cells and all of the RMS cells that contain GABA stain positive for $\mathrm{TuJ} 1$. These data collectively indicate that GABA is tonically released from neuronal precursors and limits the speed of neuronal precursor migration via $\mathrm{GABA}_{\mathrm{A}} \mathrm{R}$ activation. To prevent $\mathrm{GABA}$ accumulation and $\mathrm{GABA}_{\mathrm{A}} \mathrm{R}$ desensitization, GABA needs to be removed from the extracellular space. We indeed found that astrocyte-like cells, which were identified by positive GLAST immunostaining, express GABA transporters GAT4 on processes ensheathing GAT4-negative neuronal precursors. GAT4 is found in astrocytes in other brain regions (Borden, 1996), suggesting that SVZ astrocyte-like cells and astrocytes share similar functions. Although GAT1 is highly expressed in brain cells (Borden, 1996), it was not present in SVZ cells at the age studied. Inhibition of GABA transporters with a GAT4 blocker (SNAP5114) significantly decreased the speed of cell migration and increased GABA levels in the supernatant from RMS explants. These data suggest that astrocyte-like cells provide a microenvironment around migrating neuronal precursors in which ambient GABA levels, $\mathrm{GABA}_{\mathrm{A}} \mathrm{R}$ activation, and the speed of precursor migration are tightly regulated by GABA uptake into astrocyte-like cells (Fig. 7).

$\mathrm{GABA}_{\mathrm{A}} \mathrm{R}$ activation reduces the speed of neuronal precursor migration by interfering with intracellular $\mathrm{Ca}^{2+}$ signaling As expected, altering intracellular $\mathrm{Ca}^{2+}$ signaling with BAPTA-AM decreased the speed of neuronal precursor migration. Similarly, decreasing extracellular $\mathrm{Ca}^{2+}$ with EGTA reduced the migration rate, presumably by altering intracellular $\mathrm{Ca}^{2+}$ signaling. Consistent with the lack of effect of cell depolarization (with high $\mathrm{K}^{+}$) on cell migration, blockade of voltagegated $\mathrm{Ca}^{2+}$ channels did not alter the speed of cell migration. Application of 2-APB, which blocks $\mathrm{Ca}^{2+}$ release from $\mathrm{IP}_{3}-$ sensitive intracellular $\mathrm{Ca}^{2+}$ stores, reduced the speed of cell migration and prevented the effect of GABA and bicuculline on the migration rate. Although 2-APB also blocks store-operated $\mathrm{Ca}^{2+}$ channels (Peppiatt et al., 2003), a regulation of cell migration by store-operated $\mathrm{Ca}^{2+}$ entry during GABA application is unlikely, because cell depolarization, which inhibits store-operated $\mathrm{Ca}^{2+}$ entry in other cell types (Wang and van Breemen, 1999; Wang et al., 2000; Kajiya et al., 2003), did not alter the migration rate. These data suggest that GABA via $\mathrm{GABA}_{\mathrm{A}} \mathrm{R}$ activation reduces the speed of neuronal precursor migration by interfering with $\mathrm{Ca}^{2+}$ release from intracellular $\mathrm{Ca}^{2+}$ stores through an unknown pathway.

\section{Function of GABA signaling on neuronal precursor migration} in the SVZ and RMS

As schematized in Figure 7, GABA released from neuronal precursors activates $\mathrm{GABA}_{\mathrm{A}} \mathrm{Rs}$ in an autocrine-paracrine manner and influences the migration rate and also proliferation (Nguyen et al., 2003) of neuronal precursors. Because GABA release is enhanced by cell depolarization and GABA depolarizes neuronal 
precursors (Wang et al., 2003a), increases in ambient GABA levels are expected to promote GABA release. However, accumulation of ambient GABA is prevented by uptake into astrocyte-like cells, which ensheath chains of migrating precursors (Lois et al., 1996; Doetsch et al., 1997; Peretto et al., 1997) and thus maintain a proper balance between the levels of GABA and GABA release. It is conceivable that astrocyte-like cells create a microgradient of GABA concentration inside the chains of neuronal precursors. Precursors in contact with astrocyte-like cells may migrate faster than those in the middle of the chains where GABA concentration may be the highest. Cells inside the clusters may migrate at a lower speed and may be searching for directional cues before migrating at higher speed toward the olfactory bulb.

Overall, GABA uptake into astrocyte-like cells plays a fundamental role in clearing GABA released from neuronal precursors and regulating the behavior of neuronal precursors. Changes in the functional state of astrocyte-like cells or interactions with GABA release and uptake could profoundly affect postnatal neurogenesis.

\section{References}

Barker JL, Behar T, Li YX, Liu QY, Ma W, Maric D, Maric I, Schaffner AE, Serafini R, Smith SV, Somogyi R, Vautrin JY, Wen XL, Xian H (1998) GABAergic cells and signals in CNS development. Perspect Dev Neurobiol 5:305-322.

Belluzzi O, Benedusi M, Ackman J, LoTurco JJ (2003) Electrophysiological differentiation of new neurons in the olfactory bulb. J Neurosci 23:10411-10418.

Borden LA (1996) GABA transporter heterogeneity: pharmacology and cellular localization. Neurochem Int 29:335-356.

Boulder Committee (1970) Embryonic vertebrate central nervous system: revised terminology. Anat Rec 166:257-261.

Carleton A, Petreanu LT, Lansford R, Alvarez-Buylla A, Lledo PM (2003) Becoming a new neuron in the adult olfactory bulb. Nat Neurosci 6:507-518.

Chebib M, Johnston GA (1999) The "ABC" of GABA receptors: a brief review. Clin Exp Pharmacol Physiol 26:937-940.

Doetsch F, Alvarez-Buylla A (1996) Network of tangential pathways for neuronal migration in adult mammalian brain. Proc Natl Acad Sci USA 93:14895-14900.

Doetsch F, Garcia-Verdugo JM, Alvarez-Buylla A (1997) Cellular composition and three-dimensional organization of the subventricular germinal zone in the adult mammalian brain. J Neurosci 17:5046-5061.

Edwards FA, Konnerth A, Sakmann B, Takahashi T (1989) A thin slice preparation for patch clamp recordings from neurones of the mammalian central nervous system. Pflügers Arch 414:600-612.

Forscher P, Oxford GS (1985) Modulation of calcium channels by norepinephrine in internally dialyzed avian sensory neurons. J Gen Physiol 85:743-763.

Fueshko SM, Key S, Wray S (1998) GABA inhibits migration of luteinizing hormone-releasing hormone neurons in embryonic olfactory explants. J Neurosci 18:2560-2569.

Garcia-Verdugo JM, Doetsch F, Wichterle H, Lim DA, Alvarez-Buylla A (1998) Architecture and cell types of the adult subventricular zone: in search of the stem cells. J Neurobiol 36:234-248.

Haydon PG (2001) GLIA: listening and talking to the synapse. Nat Rev Neurosci 2:185-193.

Hille B (1992) Calcium channels. In: Ionic channels of excitable membranes, pp 83-114. Sunderland, MA: Sinauer.

Kajiya H, Okamoto F, Fukushima H, Takada K, Okabe K (2003) Mechanism and role of high-potassium-induced reduction of intracellular $\mathrm{Ca}^{2+}$ concentration in rat osteoclasts. Am J Physiol 285:C457-C466.

Kakita A, Goldman JE (1999) Patterns and dynamics of SVZ cell migration in the postnatal forebrain: monitoring living progenitors in slice preparations. Neuron 23:461-472.

Komuro H, Rakic P (1996) Intracellular $\mathrm{Ca}^{2+}$ fluctuations modulate the rate of neuronal migration. Neuron 17:275-285.

Komuro H, Rakic P (1998) Orchestration of neuronal migration by activity of ion channels, neurotransmitter receptors, and intracellular $\mathrm{Ca}^{2+}$ fluctuations. J Neurobiol 37:110-130.
Lehre KP, Levy LM, Ottersen OP, Storm-Mathisen J, Danbolt NC (1995) Differential expression of two glial glutamate transporters in the rat brain: quantitative and immunocytochemical observations. J Neurosci 15:1835-1853.

Levison SW, Goldman JE (1993) Both oligodendrocytes and astrocytes develop from progenitors in the subventricular zone of postnatal rat forebrain. Neuron 10:201-212.

Lois C, Alvarez-Buylla A (1994) Long-distance neuronal migration in the adult mammalian brain. Science 264:1145-1148.

Lois C, Garcia-Verdugo JM, Alvarez-Buylla A (1996) Chain migration of neuronal precursors. Science 271:978-981.

Luskin MB (1993) Restricted proliferation and migration of postnatally generated neurons derived from the forebrain subventricular zone. Neuron 11:173-189.

Luskin MB (1998) Neuroblasts of the postnatal mammalian forebrain: their phenotype and fate. J Neurobiol 36:221-233.

MacDonald JF, Mody I, Salter MW (1989) Regulation of N-methyl-Daspartate receptors revealed by intracellular dialysis of murine neurones in culture. J Physiol (Lond) 414:17-34.

Murase S, Horwitz AF (2002) Deleted in colorectal carcinoma and differentially expressed integrins mediate the directional migration of neural precursors in the rostral migratory stream. J Neurosci 22:3568-3579.

Nguyen L, Malgrange B, Breuskin I, Bettendorff L, Moonen G, Belachew S, Rigo JM (2003) Autocrine/paracrine activation of the $\mathrm{GABA}_{\mathrm{A}}$ receptor inhibits the proliferation of neurogenic polysialylated neural cell adhesion molecule-positive $\left(\mathrm{PSA}_{\mathrm{NCAM}}{ }^{+}\right.$) precursor cells from postnatal striatum. J Neurosci 23:3278-3294.

Peppiatt CM, Collins TJ, Mackenzie L, Conway SJ, Holmes AB, Bootman MD, Berridge MJ, Seo JT, Roderick HL (2003) 2-Aminoethoxydiphenyl borate (2-APB) antagonises inositol 1,4,5-trisphosphate-induced calcium release, inhibits calcium pumps and has a use-dependent and slowly reversible action on store-operated calcium entry channels. Cell Calcium 34:97-108.

Peretto P, Merighi A, Fasolo A, Bonfanti L (1997) Glial tubes in the rostral migratory stream of the adult rat. Brain Res Bull 42:9-21.

Rothstein JD, Martin L, Levey AI, Dykes-Hoberg M, Jin L, Wu D, Nash N, Kuncl RW (1994) Localization of neuronal and glial glutamate transporters. Neuron 13:713-725.

Saghatelyan A, De Chevigny A, Schachner M, Lledo PM (2004) Tenascin-R mediates activity-dependent recruitment of neuroblasts in the adult mouse forebrain. Nat Neurosci 7:347-356.

Shibata T, Yamada K, Watanabe M, Ikenaka K, Wada K, Tanaka K, Inoue Y (1997) Glutamate transporter GLAST is expressed in the radial glia- astrocyte lineage of developing mouse spinal cord. J Neurosci 17:9212-9219.

Stewart RR, Hoge GJ, Zigova T, Luskin MB (2002) Neural progenitor cells of the neonatal rat anterior subventricular zone express functional $\mathrm{GABA}_{\mathrm{A}}$ receptors. J Neurobiol 50:305-322.

Suzuki SO, Goldman JE (2003) Multiple cell populations in the early postnatal subventricular zone take distinct migratory pathways: a dynamic study of glial and neuronal progenitor migration. J Neurosci 23:4240-4250.

Temple S, Alvarez-Buylla A (1999) Stem cells in the adult mammalian central nervous system. Curr Opin Neurobiol 9:135-141.

Tramontin AD, Garcia-Verdugo JM, Lim DA, Alvarez-Buylla A (2003) Postnatal development of radial glia and the ventricular zone (VZ): a continuum of the neural stem cell compartment. Cereb Cortex 13:580-587.

Wang DD, Krueger DD, Bordey A (2003a) GABA depolarizes neuronal progenitors of the postnatal subventricular zone via $\mathrm{GABA}_{\mathrm{A}}$ receptor activation. J Physiol (Lond) 550:785-800.

Wang DD, Krueger DD, Bordey A (2003b) Biophysical properties and ionic signature of neuronal progenitors of the postnatal subventricular zone in situ. J Neurophysiol 90:2291-2302.

Wang X, van Breemen C (1999) Depolarization-mediated inhibition of $\mathrm{Ca}^{2+}$ entry in endothelial cells. Am J Physiol 277:H1498-H1504.

Wang X, Kim SU, van Breemen C, McLarnon JG (2000) Activation of purinergic P2X receptors inhibits $\mathrm{P} 2 \mathrm{Y}$-mediated $\mathrm{Ca}^{2+}$ influx in human microglia. Cell Calcium 27:205-212.

Wichterle H, Garcia-Verdugo JM, Alvarez-Buylla A (1997) Direct evidence for homotypic, glia-independent neuronal migration. Neuron 18:779-791.

Yang HK, Sundholm-Peters NL, Goings GE, Walker AS, Hyland K, Szele FG (2004) Distribution of doublecortin expressing cells near the lateral ventricles in the adult mouse brain. J Neurosci Res 76:282-295. 